\title{
Optimized indoor daylight for tropical dense urban environments
}

\author{
Iluminação natural interna otimizada em ambientes \\ urbanos tropicais adensados
}

\author{
lara Gonçalves dos Santos \\ Thomas Auer \\ Roberta Vieira Gonçalves de Souza
}

Abstract

$\mathbf{S}$

tudies using metrics related to dynamic sky conditions for indoor daylight performance assessment in urban environment are rare in tropical latitudes. This study applied one of these metrics, the spatial Daylight Autonomy (sDA $300,50 \% \geq 75 \%$, IES LM 83-12) for Cuiabá $\left(15^{\circ} \mathrm{S}, 56^{\circ} \mathrm{W}\right.$, Brazil $)$, a savanna climate city with a high frequency of partly cloudy skies. Parametric simulations were used to investigate the availability of daylight in dense urban areas. So daylight conditions inside a reference room with varied depths located within a continuous urban canyon were simulated with Radiance/Daysim in Grasshopper/Honeybee. Dimensions of the street and heights of front buildings (obstructions) are also varied in order to observe the relation between the sky angle and the sDA, for the four main cardinal directions. The results of regression analysis for this case study showed that among all evaluated parameters, room depth tended to be the most relevant for the optimization of indoor daylight. Finally, limitations of this approach and opportunities for further investigations were discussed.

Keywords: Daylight. Illuminance. Computer simulation. Spatial Daylight Autonomy.

\section{Resumo}

Estudos que utilizam métricas baseadas em céu dinâmico para abordagem de desempenho de iluminação natural em recintos são raros em cidades de latitudes tropicais. Este estudo aplicou a métrica Autonomia Espacial de Luz Natural (sDA

Iara Gonçalves dos Santos Technical University of Munich Munich - Germany

Thomas Auer Technical University of Munich Munich - Germany

Roberta Vieira Gonçalves de Souza

Universidade Federal de Minas Gerais Belo Horizonte - MG - Brasil

Recebido em 28/11/16 Aceito em 28/03/17

$300,50 \% \geq 75 \%$, IES LM 83-12) para Cuiabá (15ㅇ, 56 W, Brasil), uma cidade de savana com predominância de céus parcialmente nublados. Simulações paramétricas foram utilizadas para investigar a disponibilidade de iluminação natural em contexto urbano adensado. As condições de iluminação natural dentro de um recinto de profundidade variada localizado em um cânion urbano foram simuladas com Radiance/Daysim no Grasshopper/Honeybee. Dimensões da via e de altura dos edifícios frontais foram variadas com o objetivo de observar a relação entre o ângulo de céu e o SDA para as quarto orientações solares principais. Os resultados deste estudo de caso mostraram que a profundidade do recinto tende a ser o parâmetro mais relevante entre os analisados para a otimização de iluminação natural interna. Finalmente, as limitações dessa abordagem e oportunidades de futuras pesquisas foram discutidas.

Palavras-chave: Iluminação natural. Iluminância. Simulação computacional. Autonomia Espacial de Luz Natural.
\end{abstract}




\section{Introduction}

Artificial lighting accounts for about $20 \%$ of building electricity consumption worldwide, and the forecasted total electricity savings potential in building lighting by 2030 could be equivalent to all the electricity consumed in Africa in 2013 (INTERNATIONAL..., 2016).

Concurrently, in tropical locations the daylight is capable to ensure freedom from artificial light during a significant part of the day (DIAS et al., 2009). Brazil being mainly one of them, is the focus of this paper.

Daylighting has potential in saving energy and decreasing maintenance costs. Apart from that, it promotes health, productivity, and well-being. Despite of its importance, researches dedicated to daylight assessment in dense urban spaces, are relatively recent. Internationally, examples of this kind of study can be found in the publications by Tsangrassoulis et al. (1999) for estimating illuminances in urban canyons, by $\mathrm{Ng}$ (2001) for daylight design in high-density urban residential buildings using a metric for overcast sky, and by Reinhart and LoVerso (2010) about a design sequence for diffuse daylight based on design "rules of thumb".

A larger review on urban daylighting was conducted by Nasrollahi and Shokri (2016), who addressed scientific publications between the years of 1993 and 2015. The authors addressed concepts of daylighting, sky types, solar movement, and effective architectural parameters in an urban context. They shortlisted fifty papers that were considered to bring relevant knowledge to the field within this period. Among other conclusions, they recorded that:

(a) increasing the street width increases the incident quantity of radiation inside an urban canyon, while the energy consumption in a building decreases;

(b) increasing solar reflectance of exterior surfaces increases the incident daylight indoor, while the demand of energy for artificial light reduces:

(c) exterior shading devices provide visual comfort, while decrease the energy consumption of a building; and

(d) the surfaces of an urban canyon can receive uneven radiation due to solar orientation.

However, part of those conclusions are generic, and need to be analyzed in detail according to local and climate conditions, in addition to other determined aspects that make the urban analysis quite complex.
These complexities are due to the fact that daylight availability indoor is affected by the interaction of the following:

(a) the source (sky and sun);

(b) the receptor (indoor characteristics); and

(c) the mediator (characteristics of external items such as surrounding buildings, vegetation, architectural components).

The potential use of the available daylight indoor is also determined by the agent (occupant) itself.

In studies of daylight optimization, it is considered that the first three aspects must be investigated considering pre-defined demands under a metric, which allows the comparison of daylight performance between different spaces. There are several indexes [metrics] for daylight assessment indoor, as presented by Carlucci et al. (2015) - and most of them are based on illuminance levels, commonly addressed as the range of quantity of light required for the execution of an activity.

The definition of appropriate illuminance levels for human needs, as well as the most suitable metric for daylight assessment, evolves as result of novelties in the research.

Regarding illuminance levels, for instance, the Brazilian standard NBR 5413 (ABNT, 1992) provided a basic guideline for selecting illuminance levels according to the visual task executed indoor: i.e., 150lux as the average for deposits and areas not-used for continuous work, 300lux for tasks with a limited visual requirement, and 750lux for offices (ABNT, 1992). Later, the Brazilian standard NBR ISO/CIE 8995-1 (ABNT, 2013) proposed different values for indoor illuminances. According to it schools, offices, and rooms for medical regular attendance must provide values between 300750lux, departmental stores from between 300500lux and multi-use rooms for entertainment activities, a minimum of 300lux. Mardaljevic et al. (2011) highlighted that levels above 300lux are frequently perceived by occupants in offices as desirable up to a certain limit, and it is less probable that the light will be switched-on beyond 300lux.

Recent development combines the use of computer simulation for analyzing dynamic skies considering variations of sun positions and sky conditions within a period of time (usually one year). Spatial Daylight Autonomy (sDA), endorsed by the Illuminating Engineering Society of North America, IESNA (ILLUMINATING..., 2012) is one of the recent metrics proposed. The sDA reports the floor area indoor $(\%)$ that exceeds two 
thresholds (Lighting Measurement IES LM 83-12 (ILLUMINATING..., 2012)):

(a) the minimum daylight illuminance level (lux) to be achieved; and

(b) a fraction of the occupied hours per year (\%).

The sDA threshold is 300lux and $50 \%$ of the occupancy time from $8 \mathrm{am}-6 \mathrm{pm}$ considering adjustment for longitude and daylight savings time. The performance result of an analysis area can then be classified as "nominally acceptable" ( $\mathrm{sDA} \geq 55 \%)$ or "preferred" $(\mathrm{sDA} \geq 75 \%)$. These limits of $\operatorname{sDA}(300,50 \%)$ were established based on the investigation of occupant preferences in open plan offices, meeting rooms, classrooms, public lobbies and public spaces in libraries between latitudes $37^{\circ} \mathrm{N}-48^{\circ} \mathrm{N}$ in U.S.A.; and it is considered that they could be extended for areas with similar visual tasks (ILLUMINATING..., 2012). The IES LM 83-12 is adopted since October/2016 by the building rating system Leadership in Energy and Environmental Design (LEEDv4), one of the Green Building certifications that is applied in Brazil (GREEN..., 2014).

In this context, the sDA metric was chosen for this study to conduct a quantitative assessment of daylight availability in a dense urban location under predominantly partly cloudy skies.

This predominantly partly cloudy sky is typical in Savanna climate, in its duality between dry (sunny) season and a wet (rainy) season. Several cities above 500.000 inhabitants will tend to appear by 2030 in Savannas within the tropics (Figure 1). It is expected that due to higher solar altitudes in lower latitudes there might be different outcomes in the spatial distribution of indoor daylighting, affecting sDA when compared to other luminous sky conditions.

Therefore, such assessment is decisive to avoid unsatisfactory daylight conditions and hence, excessive energy consumption of indoor lighting, for these forecasted dense urban areas.

\section{Background: data and software for daylight assessment}

Climatic-based metrics for daylight assessment in an enclosed system (a room or open space) rely on atmospheric data which may be measured or calculated based on models.

The International Building Performance Simulation Association- IBPSA (INTERNATIONAL..., 2016) reports that daylight data for building simulation purposes is a field for improvements. Illuminance data is usually calculated from irradiance values. Additionally, the Association points out that information of cloud cover, which are used for daylighting and sky temperature calculations, should be used carefully, since these reports are not standards worldwide.

Figure 1 - World map with cities> 500.000 inhabitants, forecast for 2030; Savanna climate in blue colour (Köppen-Geiger “Aw” classification)

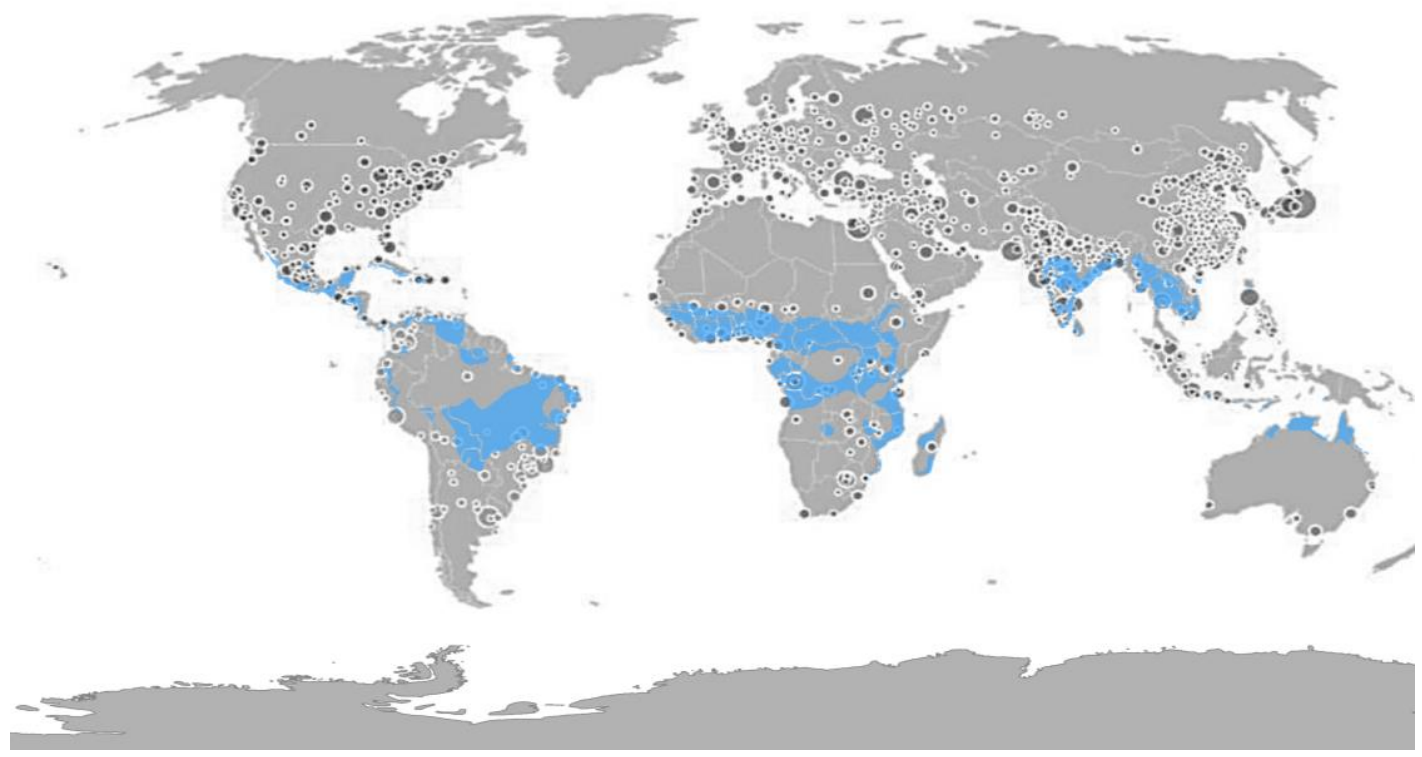

Source: adapted from Kottek et al. (2006) and United Nations (2014). 
To fulfil the lack of daylighting measurement stations with long-term data, models such as the one proposed by Perez et al. (1990) are used. These authors proposed models to predict direct, global and diffuse illuminance; diffuse irradiance or illuminance received by a tilted surface; sky zenith luminance and sky luminance angular distribution, representing different sky conditions, from clear to overcast sky. The models were developed considering data from high latitudes collected in 10 cities in U.S.A. and 3 in Europe, under conditions which ranged from "high altitude desert to temperate maritime, including humid continental, subtropical and highly polluted environments".

One of the most common weather data sets for characterizing a local climate is the Typical Meteorological Year (TMY). A TMY for computer simulation is composed of 12 months of hourly data (8,760 hours); each month is selected from different years, considering it closest proximity to a statistical weighted long-term distribution of solar radiation, dry-bulb temperature, dew point, and wind velocity: a more complete methodology than that used in the Test Reference Year (TRY) (CRAWLEY, 1998). TMY is available for more than 5000 locations worldwide under different formats such as the Solar and Wind Energy Resource Assessment (SWERA), the Indian Society of Heating, Refrigerating and Air Conditioning Engineers (ISHRAE), ASHRAE's International Weather for Energy Calculations 2.0 (IWEC2), the Chinese Standard Year Weather Data (CSWD), and the Typical Meteorological Year 3 (TMY3) (INTERNATIONAL..., 2016). Weather files built over the Brazilian Instituto Nacional de Meteorologia (INMET) data also use the TMY methodology (RORIZ, 2012). The TMY files may be converted to different formats which are readable by building/urban simulation packages, i.e. "epw". Recent versions of weather files for computer simulation based in the TMY adopt the model by Perez et al. (1990) (U.S..., 1995).

Concerning software for daylight simulations. Bhavani and Khan (2011) described the features of some of them: Radiance, Relux, ADELINE, DIALux, Light scope, Inspirer, Rayfront, 3D studio MAX, Superlite, Lumen Micro, Specter, ESP vision, Light works and DAYSIM. In Brazil, Troplux and Apolux are avaible varieties.

Daysim/Radiance is one of the most used software for indoor analysis. Radiance was developed in the Lawrence Berkeley National Laboratory in the 1980 `s. It calculates luminance required for visualization using backward ray-tracing, a technique in which the light is traced from the observer to the source(s), and it calculates illuminances for a selected type of sky. Daysim uses the algorithms of Radiance as a foundation to calculate illuminance and luminance profiles from a weather file (REINHART, 2006), becoming known as Daysim/Radiance. Daysim/Radiance incorporates a model based in Perez et al. (1990) for internal calculations of dynamic skies.

Recent parametric studies use Rhinoceros to conduct the simulations: i.e., Wagdy et al. (2015). Rhinoceros is a software for three-dimensional computer graphics and computer-aided design (CAD) which can incorporate a graphical algorithm editor called Grasshopper. The Ladybug Analysis Tools in turn connects Grasshopper to various simulation engines such as EnergyPlus, Radiance, and Daysim for building energy, comfort, daylighting and lighting simulations ${ }^{1}$.

\section{Urban daylight in the tropics}

In the tropics, Assis and Valadares (1995) proposed a mathematic model to be incorporated by urban legislation of the city of Belo Horizonte $\left(19^{\circ} 55^{\prime} \mathrm{S}\right.$, Brazil, partially Savanna climate), in order to favor daylight and insolation. More than 20 years ago, they defined thresholds similar to the concept of sDA, except for the spatial percentage of indoor floor area. The research adopted 150lux in the work plane of residences; $80 \%$ time of the year from $8 \mathrm{am}$ to $4 \mathrm{pm}$; under different values of external horizontal illuminances found in literature (the higher value being of 26.4klux), as the premise. Subsequently, the authors demarcated the minimum sky angle for the area. The sky angle was determined between the vertical plane containing the window and the top of the opposite building, with a vertex located on the top of the window sill of a defined space on the ground floor. Thus, a minimum sky angle of $27^{\circ} 30^{\circ}$ was defined for preserving daylight in the residential urban areas. The authors recommended that 150lux should not be adopted in mixed land use designating at least 300lux for offices and commercial activities and therefore new sky angles should be determined in those cases.

Indeed, urban planning in rapidly growing cities face the challenge to promote the concept of buildings prepared for flexibility over time, and to shelter mixed activities simultaneously. Henceforth, minimum illuminance levels based on the demands of a unique typology with lower requirement levels, such as the residential one,

1<http://www.food4rhino.com/app/ladybug-analysis-tools>. Accessed: 16/Feb/2017. 
could not be adopted as a reference for the entire urban design.

More recently, Laranja et al. (2012) evaluated the effect of solar orientation on the indoor daylight availability of a room located in the coastal city of Vitoria $\left(20^{\circ} 17^{\prime} \mathrm{S}\right.$, Brazil, Savanna climate). They used the software Troplux for an annual simulation of three CIE skies (with a daily schedule of 13 hours from $6 \mathrm{am}-6 \mathrm{pm})$. The output was the average global illuminance based on a dynamic metric assessment that computed indoor values between 100-2000 lux. The room was modelled with dimensions of $2.60 \times 3.85 \times 2.60 \mathrm{~m}$ (width $\mathrm{x}$ depth $\mathrm{x}$ height, $\mathrm{m}$ ), and internal reflectances of 20/50/85 \% (floor, walls, ceiling, \%). One window on the façade, was defined with clear glass, sill height of $1.10 \mathrm{~m}$, and dimension of 1/8th of the area of the room floor according to local laws, resulting in a total area of $1.25 \mathrm{~m}^{2}$. The room was located in the 4th floor of a building on a $20 \mathrm{~m}$ wide street. Three front buildings were modelled with different heights $(37.6 \mathrm{~m} ; 37.6 \mathrm{~m}$ and $29 \mathrm{~m}$ ), different distances from the sidewalk, and different spaces between them. The window was simulated facing to four different solar orientations $(\mathrm{N}, \mathrm{S}, \mathrm{E}, \mathrm{W})$. The results for this case study showed small differences of indoor daylight under the expected homogeneous output from CIE sky type 3 (overcast). Under the CIE sky type 7 (partially cloudy) and type 12 (clear), the window oriented to North resulted in the highest illuminance percentage, to South the lowest, while to East and West presented similar percentages. The reasons for the choice of the obstructions configured in the study were not described in the paper, neither references of external reflectances.

Scalco and Pereira (2016) proposed a method to analyze the impact of buildings in static daylight performance of a neighborhood in Brazil. Different urban configurations with the same built area were compared. The software Apolux was used, assuming partially cloudy sky. The results indicated that a higher percentage of adverse impacts occurred in regular, homogeneous building configurations with 5 floors and building footprint of $75 \%$ of the gross area of the plot. Comparatively, better results were observed in taller buildings with low building footprint. Considering the outdoor reflection by obstructions, evaluation of different type of skies, and use of dynamic simulation, were some of the suggestions for future studies.

Furthermore, Paule and Kaempf (2016) assessed the daylight performance of rooms in the urban context of Bogotá ( $4^{\circ} 37^{\prime} \mathrm{N}$, Colombia). They compared the results provided by two software: one specialized for the room scale (DIAL), and the other for urban scale (CitySIM). They established a threshold, as per the number of annual hours during which the indoor illuminance exceeds 300lux for two points located inside each room. This study demonstrated that there were discrepancies in the results of the points located far from the façade, probably due to indoor reflectances. Indirectly, the study evidenced that the tool used for urban assessment needed improvements for quantifying indoor reflectances. The authors suggested to create a link between the two software for complementing the capabilities of both.

CitySIM was used before by Martins et al. (2013) in a study on the impact of urban form on the energy demand of buildings in the city of Maceió $\left(9^{\circ} 39^{\prime}\right.$ $S$ ), computing the demand for indoor artificial lighting and climatization. In this case, the authors identified that total built density, verticality, compactness, and the mean prospectus (ratio of the canyon height to canyon width, H/W) had a major impact on quantitative daylight.

Outside the tropical region, Reinhart (2014) exposed the relation of daylight and the depth of a space according to design guides from the USA, UK and Germany. As a rule of thumb, the depth of a daylit area of a sidelit space in these documents lies between 1 to 2.5 times the dimension of the window head height. The author used computer simulation to examine this rule of thumb. One of the models was a reference office room $(3.6 \times 8.2 \times 2.8 \mathrm{~m}$, WWR of $45 \%$ ), positioned inside an urban canyon of uniform height. This model was rotated in four cardinal directions and simulated using annual weather files of three cities (latitudes $>33^{\circ} \mathrm{N}$ ). A linear decrease of the daylit area as a consequence of the increase of the front obstruction was observed.

Later, Saratsis (2015) proposed a simulation-based framework for urban zoning rules from daylight. The method was applied for different urban typologies considering the city of New York $\left(40^{\circ} 43^{\prime} \mathrm{N}\right.$, U.S.A.). Focusing on the maximum daylight performance potential of a neighborhood, buildings were modelled with a window-to-wall ratio of $100 \%$, glazing with a visible transmittance of $50 \%$, and blinds with $50 \%$ cut-off value in case of illuminances crossing 20.000lux. Blocks were simulated using a tool named Urban Daylight, pursuing the $\operatorname{sDA}(300 / 55 \%)$.

Likewise, Wagdy et al. (2015) investigated the optimum window-to-wall-ratio (WWR) for dwellings of informal settlements in Cairo $\left(30^{\circ} 3^{\prime} \mathrm{N}\right.$, Egypt, hot desert climate). They assessed $\operatorname{sDA}(300 / 55 \%)$ of a south-oriented room of dimensions 4.0x6.0x3.0 (wxdxh, $\mathrm{m})$ and reflectances 20/50/80 (floor, walls, ceiling, \%), under different $\mathrm{H} / \mathrm{W}$ ratio (streets varying from 4$8 \mathrm{~m}$ wide, front buildings heighted up to nine floors) 
using Rhinoceros/Daysim. Among other results, they concluded that daylight reflected from the ground had a lower impact in overall indoor daylight.

It is important to point out that the typology of a continuous urban canyon is being intensively used in researches of daylight in the urban environment (NASROLLAHI; SHOKRI, 2016), probably because it can represent complex repeated urban patterns in a simplified way (STRØMANNANDERSEN; SATTRUP, 2011).

It is also remarkable that different researches adopted a $3 \mathrm{~m}$ wide room for daylight analysis (CABÚS, 2005; REINHART, 2014; ALBUQUERQUE; AMORIM, 2012). For instance, the dimension of a test room of $3.0 \times 9.0 \times 2.7 \mathrm{~m}$ (wxdxh) was implemented for software validation (AIZLEWOOD et al., $1996^{2}$ apud CABÚS, 2005). Studies of Radiance were developed using the "typical [dimension] of a deep-plan office module" of $3.0 \times 9.0 \times 2.7 \mathrm{~m}(\mathrm{wxdxh})$ with a single window of $2.6 \mathrm{~m}$ width and $1.5 \mathrm{~m}$ height (MARDALJEVIC, 1999).

The dimension of $3 \mathrm{~m}$ wide represents somehow a worst case in the urban scene, where wider rooms might be commonly found. In fact, in narrow rooms the view of the sky at points distanced farther from the façade is decreased in comparison to wider rooms of same WWR. Thus, the sDA results would be even better in other typologies with potentially wider rooms, like residences.

After this brief review of researches in urban daylight assessment, the following session presents the main purpose of this study.

\section{Objective}

The main goal of this paper was to quantify and understand the influence of parameters related to urban planning strategies on indoor daylight in predominant partly cloudy sky in the tropical region, using a dynamic metric named sDA. Furthermore, the study aimed to identify the conditions within an urban context that are sufficient for providing a minimum daylight illuminance level to a reference room to allow the execution of indoor daily multi-purpose activities with less dependence on artificial lighting under these sky conditions. Additionally, the relevance of outdoor reflectance in obstructed sites were discussed.

${ }^{2}$ AIZLEWOOD, M. et al. The Development of a Reference Data Set for Lighting Computer Programs. CIBSE - National Lighting Conference. Bath - UK: CIBSE, 1996.

\section{Method}

A parametric computer simulation of a reference room in the city of Cuiabá was executed using Grasshopper for Rhinoceros, with Radiance/Daysim interfaced by Honeybee (v.0.0.59) and Ladybug (v.0.0.62, jan-28-2016). The room intended to represent a "worst case" scenario: located in the ground floor of a building, in a dense urban context. The parametric parameters were building depth (related to the depth of the reference room), solar orientation of facades, height of front obstructions, and street width. The pursued outputs were $\operatorname{sDA}(300,50 \%) \geq 75 \%$.

\section{Selected case-study: Cuiabá and its weather files}

Cuiabá $\left(15^{\circ} 35^{\prime} \mathrm{S}, \quad 56^{\circ} 05^{\prime} \mathrm{O}, \quad\right.$ Brazil $)$ is an intercontinental tropical city with a Savanna climate with ca. 863.509 inhabitants, located at an altitude of $151.34 \mathrm{~m}$. The reasons for selecting Cuiabá as a case study were its considerable sky variations throughout the year; its low latitude; the availability of a reliable weather file; and the intention of the municipality in increasing its density.

As stated by Alves et al. (2013), the sky cover condition in the urban area of Cuiabá is influenced by diverse factors, such as cloudiness and atmospheric combustion products. Another phenomenon is a typical characteristic of the central-western Brazilian territory: outbreaks of fire in the surrounding native vegetation. Therefore, during the dry season, when sky should ideally be clear, the particles diffused by this burning biomass, reduce the incident solar radiation. The authors observed the effect of this type of incident in Cuiabá and reported that in 2005 the project Solar and Wind Energy Resource Assessment (SWERA), which mapped solar energy resources in the country using a model of radiative transfer.

Lamberts et al. (2015) statistically compared weather files for Cuiabá. The authors analysed two available files, INMET and SWERA, in terms of temperature and solar radiation, both prepared in the TMY (Typical Meteorological Year) format. SWERA project initiated in 2001 with the focus on making reliable data of solar radiation and wind available. The INMET file results of data measured in official meteorological stations between 2000 and 2010. One of the most remarkable results of this study by Lamberts et al. (2015) is that the differences of horizontal diffuse radiation between both the files are considerable. The report did not 
present any imprecision of both files, neither suggested that one file should be preferred rather than the other. However, they informed that before the analysis it was necessary to fulfil many existing data gaps in the INMET file, without detailing the extension of this problem. In light of this information, for the purposes of this study, the SWERA weather file was chosen for the simulations (named BRA_CuiabaMarechal.Ron.833620_SWERA). It is important to point out that in the TMY category the files ideally result of long term measurement data: a minimum of 30 years is recommended (U.S..., 1995). None of these files seem in compliance with this recommendation.

For a better understanding of the overall data and annual sky conditions in this selected SWERA file, it was analysed using the software ClimateConsultant v6. The generated outputs presented an annual average mean of sky cover around $57 \%$, varying between $29 \%$ and $80 \%$. The monthly lowest sky cover average is $30 \%$ in the dry season, and the maximum of $81 \%$ in the wet season. Considering the annual illumination based on daylit hours, the global horizontal average ranges between 10-92klux (mean of 49klux), while the direct normal average ranges from 9-59klux (mean of 32klux) (Figure 2, column “A”).

\section{Selected input and output parameters}

A hypothetical continuous urban canyon was built in a virtual environment (Figure 3), assuming that it could be the worst case in terms of poor daylight compared to a non-continuous canyon.
Therein, a multi-purpose empty room on the ground floor is modelled. The room was defined as a commercial/ office/ multi-purpose room, since in mixed urban blocks those activities are located commonly in the levels of pedestrians, while residences are located on the upper floors. The dimensions where chosen based on a literature review: $3.0 \times 2.7 \mathrm{~m}$ (width $\mathrm{x}$ height), both kept constant during the entire experiment. Particularly, the dimensions of the side of the canyon that contains the room were also kept constant.

Clear glazing, typical in the local real-estate market, was located $1 \mathrm{~m}$ above the floor with $1.8 \mathrm{~m}$ height. Dirt depreciation factor of window was neglected and visible transmittance was of 0.88 . The resulting window-to-wall ratio was approximately $60 \%$, measured from inside and without frames. This exaggerated WWR of $60 \%$ is not usual, neither recommended due to thermal issues. However, it was intended to represent the maximum effective available indoor daylight. If the desired levels of sDA are barely achieved, the conditions in reality might be worse because of lower WWR values, dirt depreciation due to pollution, presence of additional obstructions such as trees, etc.

For this study, four factors (urban parameters) were varied on four levels, resulting in a total of $4^{4}=256$ combinations. Factors acknowledged from previous researches as the ones playing important role in indoor daylight performances, were selected for these parametric simulations. The range values of these parameters were chosen partially based on literature and partially from the analysis of characteristics of dense cities in tropical regions.

Figure 2 - Example of graphic generated for the analysis of the weather data (city of Cuiabá): Hourly illumination (only daylit hours), Direct normal and Global Horizontal (klux) in the year

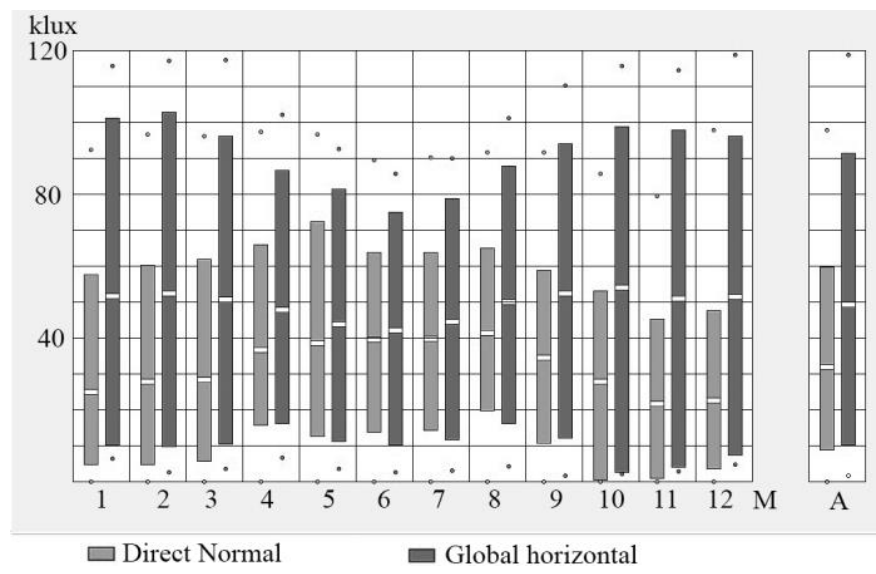

Note: $M=$ Month (i.e., $1=$ January); and A: Annual.

Source: adapted from ClimateConsultant. 
Figure 3 - Simplified perspective of the model used in the parametric simulation (Sketch Up)
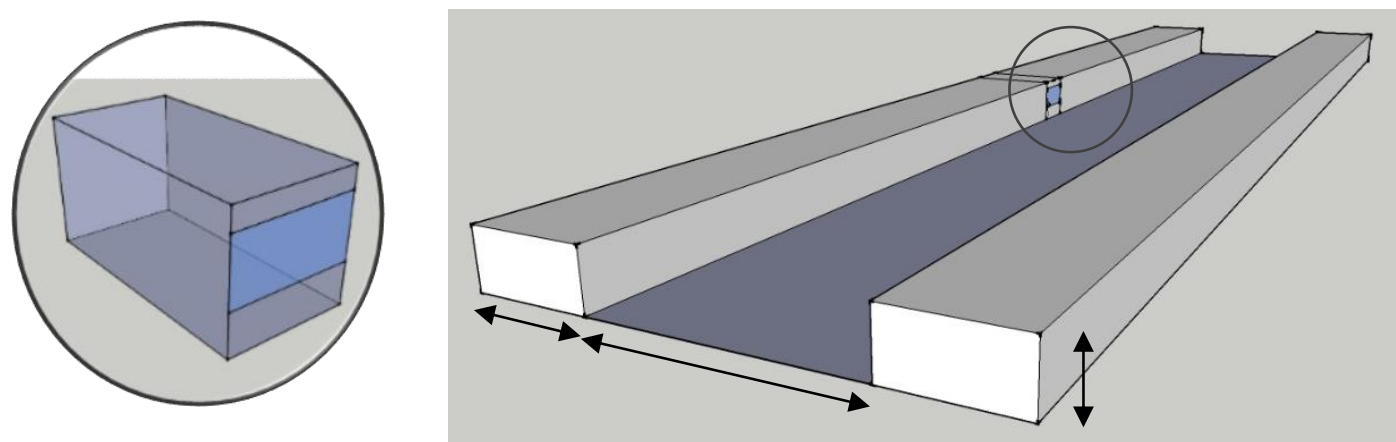

Note: Left: the reference room. Above: The continuous urban canyon containing the reference room. Double arrows indicate the variable dimensions of street width, front obstruction height, and room depth.

Additionally, these ranges were selected based on a preliminary simulation in which one value was changed at each run, to pre-evaluate their potential influence on the results and on the time-demand of pilot simulations. Then, accordingly, several combinations were chosen due to restrictions of computer time-processing.

Table 1 illustrates the alterations demarcated on the depth of the reference room $(6,7,8,9 \mathrm{~m})$, solar orientation of room facade $(\mathrm{N}, \mathrm{S}, \mathrm{E}, \mathrm{W})$, height of buildings determining front obstruction $(12,24,48$, $72 \mathrm{~m}$ - respectively of $4,8,16,24$ floors), and street width $(5,10,15,20 \mathrm{~m})$. The heights of front obstructions were chosen to represent different vertically dense buildings. The minimum depth of the reference room exploited the rule of two times the height of the window head to optimize daylight potential. Street width varied from $5 \mathrm{~m}$, representing a pedestrian passage or the measure of one car lane with one sidewalk, in which shadowing effect is significant, up to $20 \mathrm{~m}$.

Table 2 describes relevant input parameters for the simulation. The mentioned reference IES LM 83-12 (ILLUMINATING..., 2012) was adopted as the main guide in the choice of some of them.

Regarding the reflectance of façades, important parameter of this investigation, Givoni (2016) suggests for tropical regions a percentage of $40 \%$ considering mold and lack of maintenance, despite the recommendation for higher percentages in these regions for thermal benefits. This percentage was adopted, although the LM83-12 recommended a value of $30 \%$, when the outdoor reflectance is unknown.

Reinhart (2014) recommends an outdoor ground reflectance of $20 \%$ for simulation purposes. This percentage was applied in the model.

As main output, an $\operatorname{sDA}(300,50 \%) \geq 75 \%$ was established as the minimum desirable conditions for indoor daylight over a work plane height of $0.8 \mathrm{~m}$ in this room in the first floor. The value of 300lux based on the IES LM 83-12 (ILLUMINATING..., 2012) was adopted overall as an in indicator of potential energy savings with indoor lighting. In the future, this threshold and approach could be reviewed based on far-reaching surveys of occupant preferences and behavior, as well as on advanced qualitative metrics related to human comfort and health.

It is important to highlight that the sDA is recommended to be evaluated together with the Annual Sunlight Exposure (ASE), a metric that evaluates the risk of excessive daylight that potentially could cause visual discomfort. Visual comfort is not addressed in this work, and ASE is not considered - as acompensation, the "preferred" level ( $\mathrm{sDA} \geq 75 \%)$ is pursuit. Notwithstanding, "nominally acceptable" results ( $\mathrm{SDA} \geq 55 \%)$ are also discussed.

\section{Method for data treatment and analysis}

From the outputs, quality control methods were carried out aiming to verify the existence of outliers and the overall coherence of outputs before proceeding to the analysis, to:

(a) prevent unreliable results generated from software bugs, computer failure, and data treatment based on personal experience or (lack of) attention; and

(b) allow the reproduction of the experiment through methods accepted by the international community. Multiple regression analysis was undertaken to verify the correlation between the parameters and SDA percentages.

The search for outliers considered a Modified Thompson Tau $=1.954$ obtained from a student's $\mathrm{t}$ value based on $\alpha=0.05$, population of 256 and $\mathrm{df}=$ $\mathrm{n}-2$. 
Table 1 - Variation in input parameters of the 3-D model for the simulation

\begin{tabular}{l|c|c|c|c|c}
\hline \multicolumn{1}{c|}{ Parameter } & Variation & $\left(\mathbf{1}^{\text {st }}\right)$ & $\left(\mathbf{2}^{\text {nd }}\right)$ & $\left(\mathbf{3}^{\text {rd }}\right)$ & $\left.\mathbf{( 4}^{\text {th }}\right)$ \\
\hline Depth of the reference room (m) & $\left(\mathbf{1}^{\text {st }}\right)$ & 6 & 7 & 8 & 9 \\
Height of front obstruction (m) & $\left.\mathbf{( 2}^{\text {nd }}\right)$ & 12 & 24 & 48 & 72 \\
Street width (m) & $\left.\mathbf{( 3}^{\text {rd }}\right)$ & 5 & 10 & 15 & 20 \\
Orientation of façade $\left({ }^{\circ}\right)$ & $\left.\mathbf{( 4}^{\text {th }}\right)$ & 0 & 90 & 180 & 270 \\
\hline Total number of combinations $=4^{4}=256$
\end{tabular}

Table 2 - Input parameters for the simulation

\begin{tabular}{l|l|l|l}
\hline \multicolumn{1}{c|}{ Parameter } & \multicolumn{1}{c|}{ Value } & \multicolumn{1}{c}{ Parameter } & \multicolumn{1}{c}{ Value } \\
\hline Ambient bounces & 6 & Occupancy (local time) & 8 am to 6pm \\
Ambient division & 4096 & Illuminance Threshold (lux) & $\geq 300$ \\
Quality & 2 (High) & Period of occupancy (\%) & $\geq 50$ \\
Ambient sampling & 4096 & Indoor floor area - pursued sDA (\%) & $\geq 75$ \\
Ambient accuracy & 0.1 & Reflectance of indoor floor (\%) & 20 \\
Ambient resolution & 128 & Reflectance of indoor walls (\%) & 50 \\
Specularity of materials & 0 & Reflectance of indoor ceiling (\%) & 70 \\
Roughness of materials & 0 & Outdoor ground reflectance (\%) & 20 \\
\hline
\end{tabular}

Then, a regression analysis was carried out in an attempt to create a model to predict the value of sDA from the known values of the variables which were defined within the selected urban design parameters, considering the studied conditions. The hypotheses were established as follows:

H0: M1 = 0 (Null hypothesis: slope is zero, meaning no correlation); and

$\mathrm{H} 1: \mathrm{M} 1 \neq 0$ (Alternative hypothesis: slope is different from zero in the population).

A multiple regression analysis was conducted in Excel, considering a significance level of 5\%, and it generated one equation representing the behavior of the model. The regression of each parameter separately was performed to support the analysis; nonetheless, they were not detailed here. Overall results were analysed and discussed in the following session.

\section{Results and discussion}

The sDA results obtained from variations in the urban model using Grasshopper Daysim/Radiance are presented below. No outliers were found among the outputs; therefore, no datum resulting from the simulation was excluded from the analysis.

Figure 4 presents graphics of sDa values resulting from variations in three factors: height of front obstruction (m), street distance (m), and room depth (m), for the North orientation. The " $y$ " axis (dependent variable) presents the results of $\operatorname{sDA}(\%)$ for each variation, meaning the percentage of floor area of the room which exceeded 300lux during $50 \%$ of the occupied hours of the year (8am-18pm).
The dashed lines highlight the minimum values of sDA required by LM 83-12 as "preferred" (75\%, which is the desired condition defined for this research). The " $x$ " axis (independent variable) presents the heights of the buildings that compound the front obstruction: from $12 \mathrm{~m}$ (buildings with 4 floors) to $72 \mathrm{~m}$ ( 24 floors). The results in this graphic are grouped by color: tones of blue represent street width of $5 \mathrm{~m}$, orange $10 \mathrm{~m}$, green $15 \mathrm{~m}$, and red $20 \mathrm{~m}$. Each tone represents a depth of the room.

The main results of the statistical analysis for each parameter are summarized in the Table 3.

The multiple regression analysis generated the Equation 1:

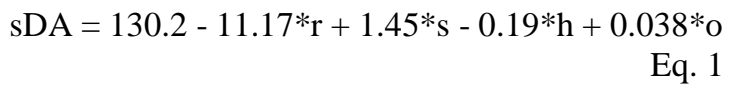

Where "r", "s", "h" and "o" represent respectively the room depth, street width, height of obstruction and facade orientation of the room.

Considering the general Equation 1 it is possible to infer that an increase in street width influenced positively in the sDA. Additionally, an increase in the height of front obstruction and in the room depth depreciates the sDA levels. Based on the pvalues $<5 \%$, there is a strong evidence that the slope was not zero in the population; therefore, the null hypothesis was rejected and it is possible to affirm that there was a correlation between the four parameters and the variation in sDA $(95 \%$ confident). These results match the ones by previous studies conducted in other cities, and therefore they indicate consistency in the simulation. 
Figure 4 - sDa (\%) $x$ height of front obstruction $(m)$ in four different street distances $(m)$, room depths $(\mathrm{m})$, and solar orientations (Continues...)

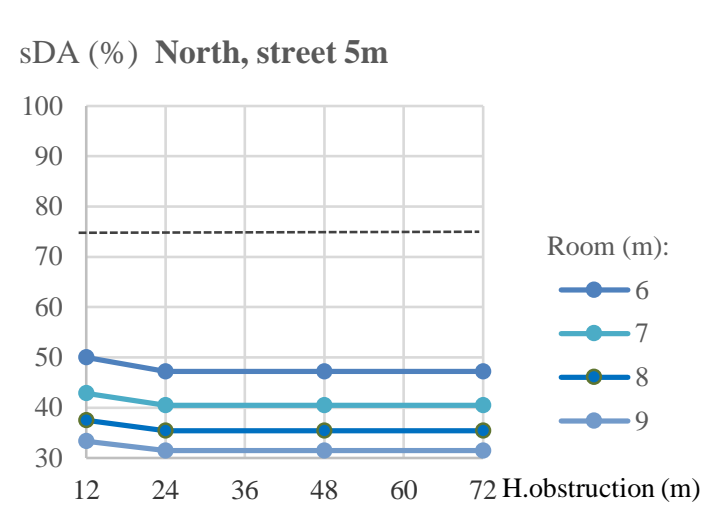

sDA (\%) South, street 5m

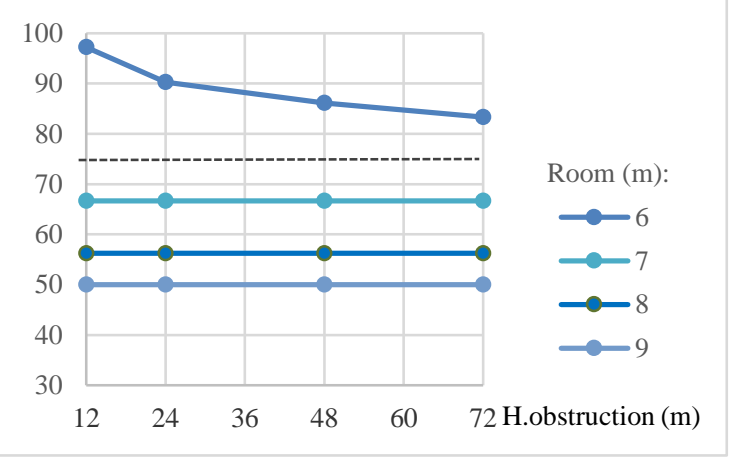

\section{sDA $(\%)$ North, street $10 \mathrm{~m}$}
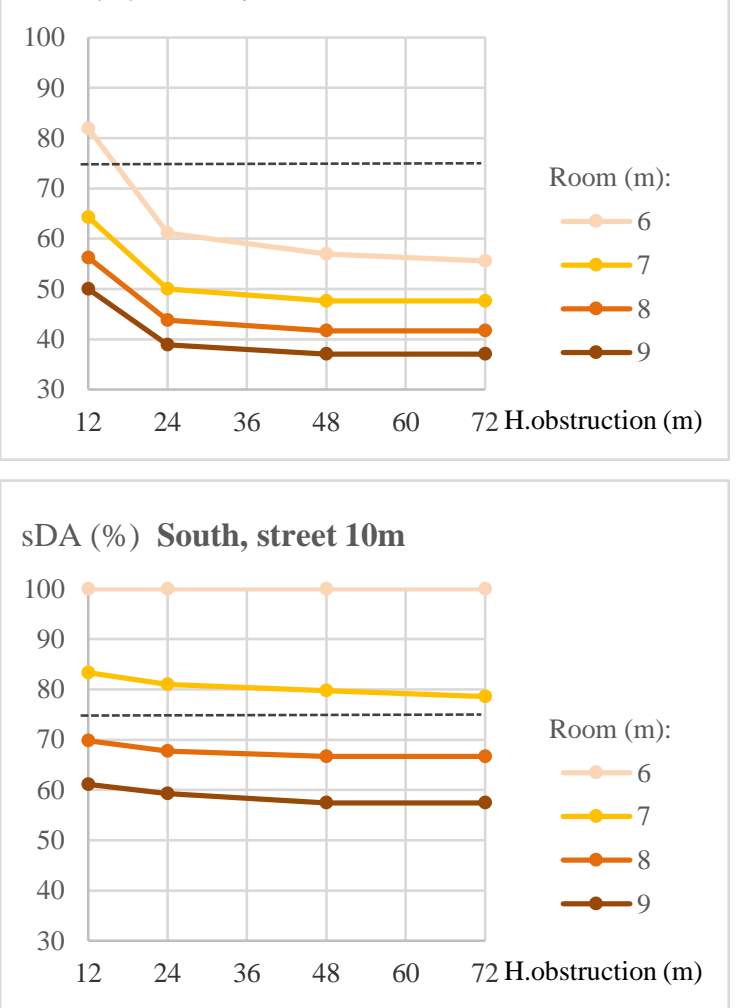

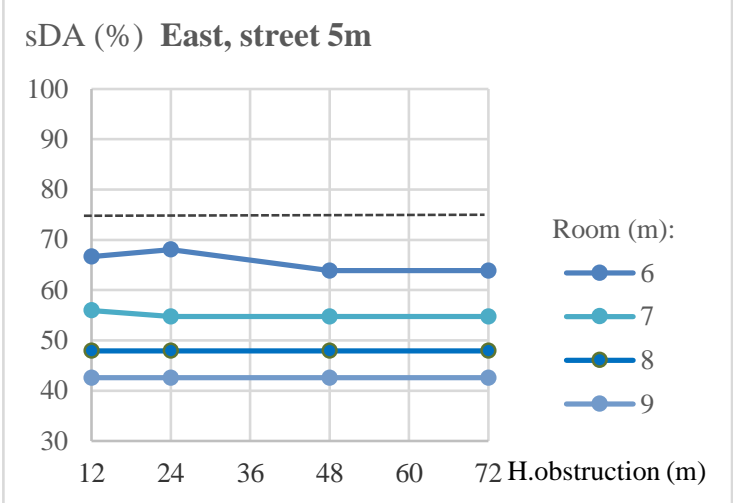

sDA (\%) West, street $5 \mathrm{~m}$

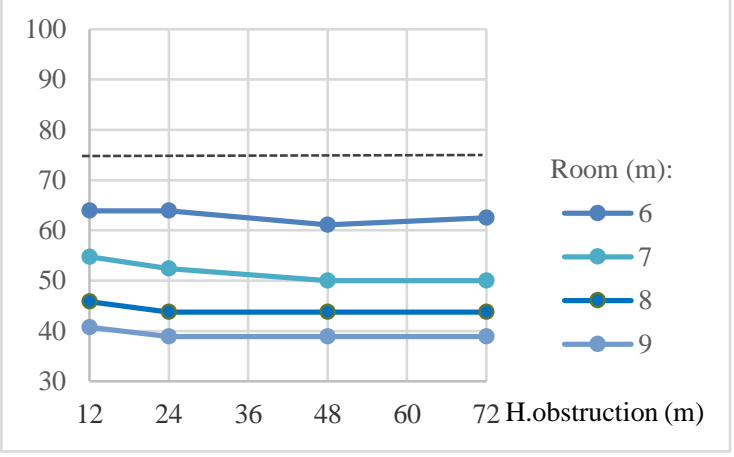

sDA (\%) East, street 10m

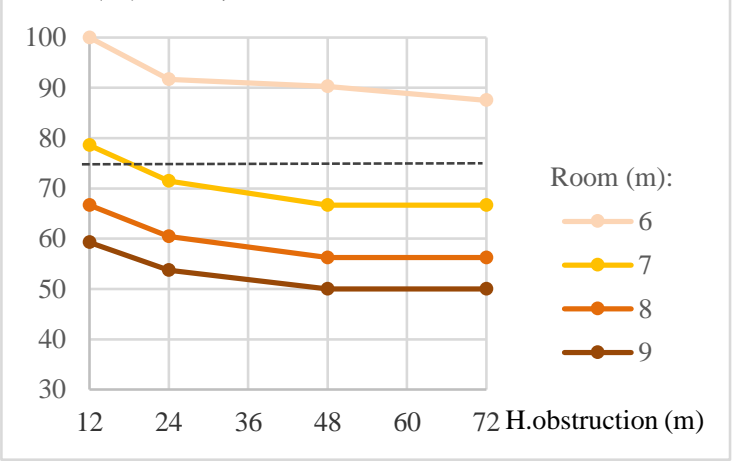

sDA (\%) West, street 10m

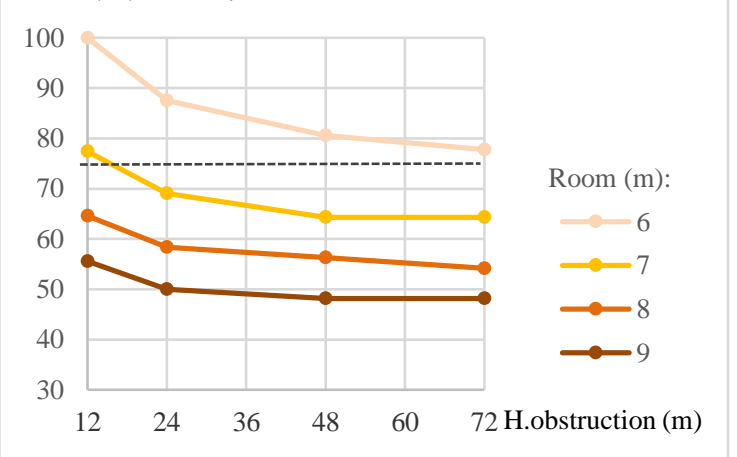


Figure 4 - sDa $(\%) \times$ height of front obstruction $(m)$ in four different street distances $(\mathrm{m})$, room depths $(\mathrm{m})$, and solar orientations (continuation)
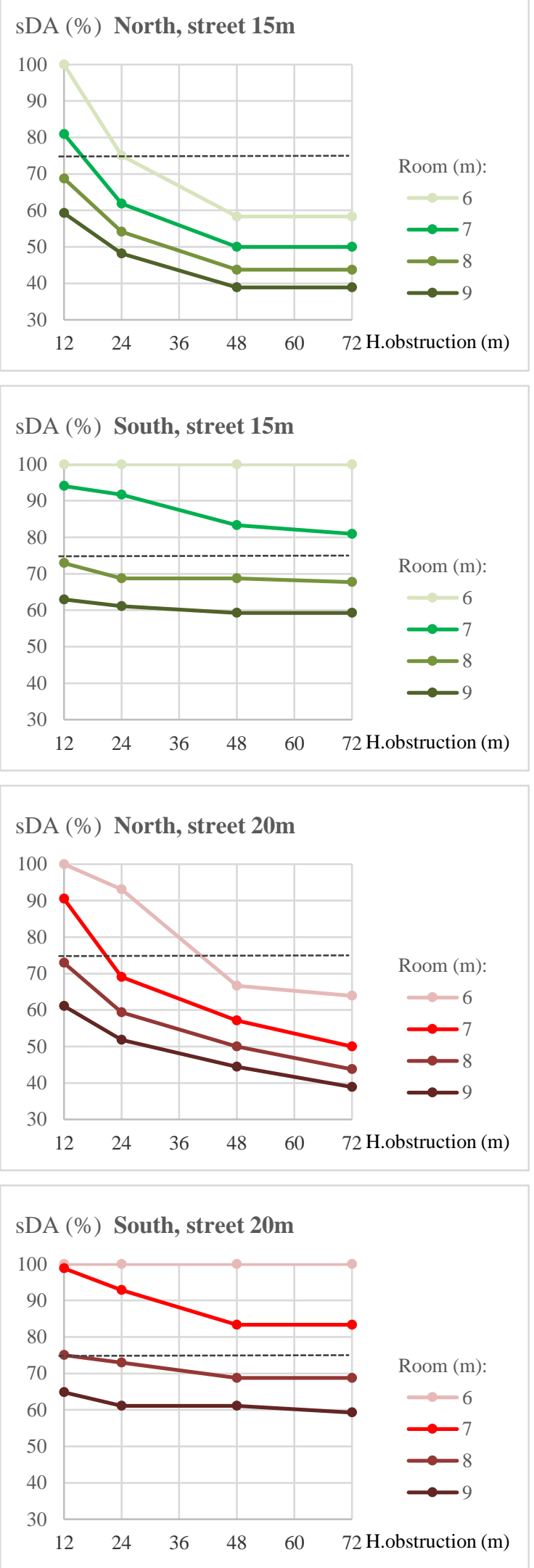

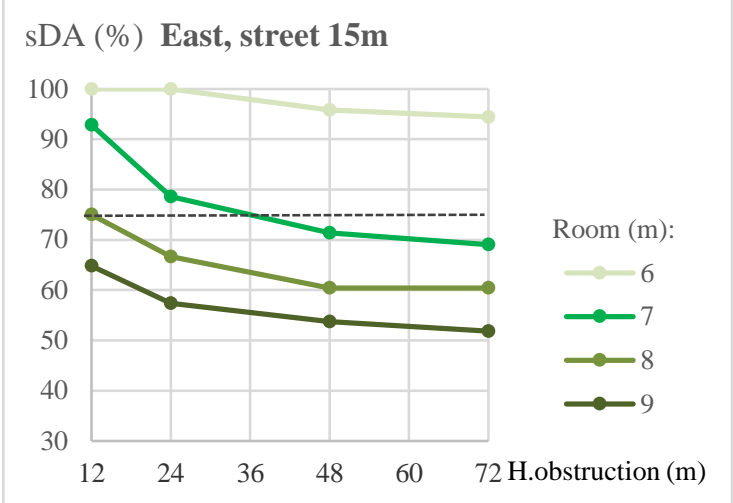

sDA (\%) West, street $15 \mathrm{~m}$

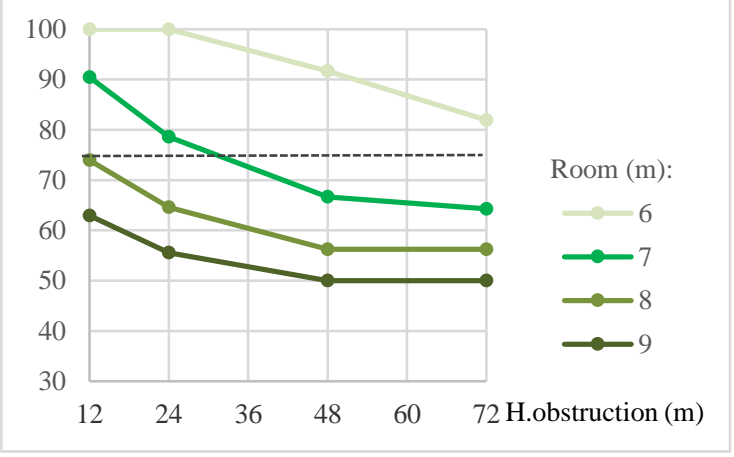

sDA (\%) East, street 20m
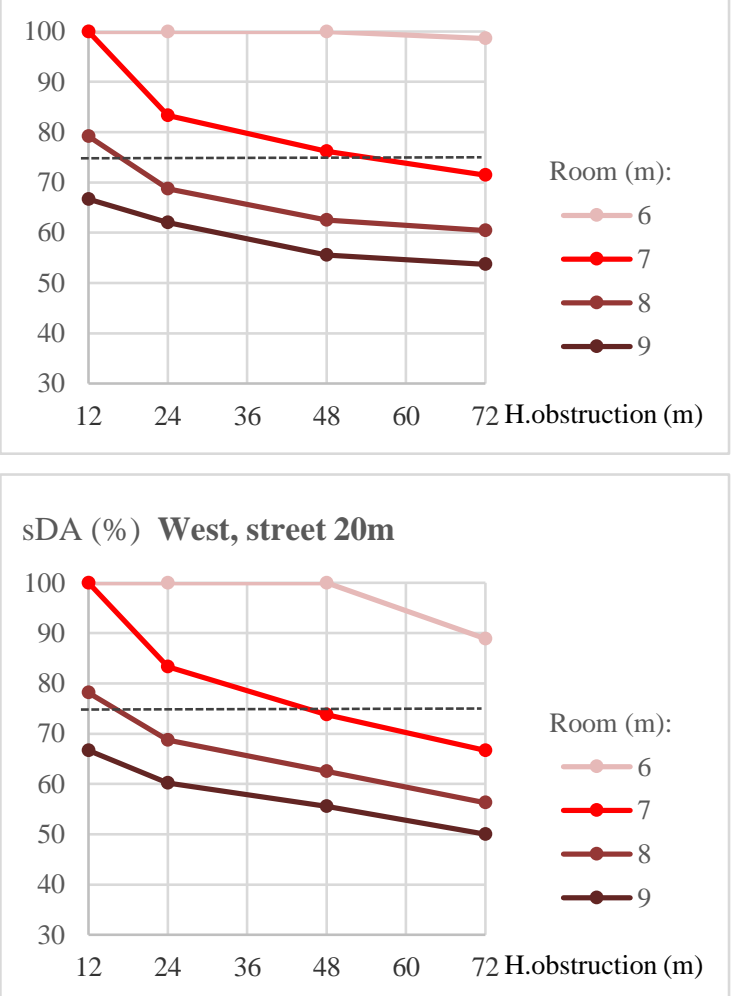
The higher R-sq value of $43.5 \%$ (Table 3 ) indicates that the room depth had the stronger correlation to sDA among the four evaluated parameters, and in other words, that $43.5 \%$ of variation in sDA was explained by room depth. This higher R-sq value also indicates that it probably presented the higher level of influence on sDA; however, a complementary study using another statistical method is necessary to confirm this possibility. Combined, all parameters explained only $71.5 \%$ (R$\mathrm{sq}=0.715)$ of the variation in $\mathrm{SDA}$; this indicates that other parameters should be considered in future simulations, to achieve a better correlation (closer or above 90\%). Considered the regression made separately only with the room depth, it is possible to affirm that each additional meter in the depth of the room decreased the value of sDA from $9.6 \%$ up to $12.7 \%$ (lower and upper values).

The orientation of the façade must be carefully interpreted: the unit was not normalized to match the others (m), and the negative sign in Equation 1 is meaningless; an additional analysis was made for this parameter. A regression considering only sDA and solar orientation results in a $\mathrm{R}$-sq $=0.04$, which indicated lower impact of solar orientation on $\mathrm{sDA}$ in face of the other parameters.

Detailing the results as per orientation, for South a room of $6 \mathrm{~m}$ depth provides $\mathrm{sDA} \geq 75 \%$ in all the cases; a $7 \mathrm{~m}$ depth the same except for the narrow street (5m width); $8 \mathrm{~m}$ depth only with maximum street width $(20 \mathrm{~m})$ and minimum obstruction height $(12 \mathrm{~m})$. Street width of $5 \mathrm{~m}$ was not favorable for daylight: only rooms of $6 \mathrm{~m}$ depth in South orientation exceeded the established value of sDA. For East, if the room is a $6 \mathrm{~m}$ depth, the $\mathrm{sDA} \geq 75 \%$ in all cases, except with the street width of $5 \mathrm{~m}$; a $7 \mathrm{~m}$ depth required street distances over $10 \mathrm{~m}$ and front obstructions up to $48 \mathrm{~m}$; a room of $8 \mathrm{~m}$ only achieved the preferred sDA if the street is $15 \mathrm{~m}$ or wider, and the external obstruction is limited to $12 \mathrm{~m}$ height.
West differs from East in two cases: $7 \mathrm{~m}$ depth (with $48 \mathrm{~m}$ of obstruction), and $8 \mathrm{~m}$ depth (with $15 \mathrm{~m}$ street width) were not sufficient. For North, an $\mathrm{sDA} \geq 75 \%$ was only achieved for room depths of $6 \mathrm{~m}$ (if street width $\geq 10 \mathrm{~m}$ and front obstruction of $12 \mathrm{~m}$ to $24 \mathrm{~m}$ ), or room depth of $7 \mathrm{~m}$ (if street has $15 \mathrm{~m}$ or $20 \mathrm{~m}$, and front obstruction only $12 \mathrm{~m}$ height). A room of $9 \mathrm{~m}$ depth did achieve results of $\mathrm{sDA} \geq 75 \%$ in any of the cases. Table 4 presents the average of sDA as per solar orientations: North was the orientation that presented lower sDA results, South and West presented very similar results of sDA, and South presented the higher sDA percentages.

The global results for solar orientation diverged from the ones obtained by Laranja et al. (2012). First, it is necessary to underline that the simulated characteristics were different in this study. Second, the last column of Table 4 presents the average of sDA considering only conditions more similar to the ones simulated by those authors: street width of $20 \mathrm{~m}$, room depth of $6 \mathrm{~m}$, obstructions of 24 and $48 \mathrm{~m}$. In this case, the major difference was related to North. The influence of the outdoor reflectance, the difference of height between the sides of the canyon, and solar path can explain the differences on the results: the hypothesis ist that front buildings acted as a "blocker" for direct sun light from the window oriented to North, while they acted as "reflectors" of light in the other orientations, producing better results of sDA. It is important to remember that the height of the reference room and adjacencies was kept constant, while the height of the front building increased. The result for North could be better if the side of the canyon where the room is located was also increased simultaneously. Further investigations should consider the simulation of different values of façade reflectance combined with a sensitivity analysis in order to understand the influence of this factor on indoor daylight performance.

Table 3 - Main outputs of ANOVA for each Regression Analysis considering the four simulated parameters

\begin{tabular}{l|c|c|c|c}
\hline \multicolumn{1}{c|}{ Parameter } & $\begin{array}{c}\text { R- } \\
\text { square }\end{array}$ & Coefficients & $\begin{array}{c}\text { Lower } \\
\mathbf{9 5 \%}\end{array}$ & $\begin{array}{c}\text { Upper } \\
\mathbf{9 5 \%}\end{array}$ \\
\hline Room depth $(\mathrm{m})$ & 0.435957 & -11.175 & -12.7457 & -9.60436 \\
Street width $(\mathrm{m})$ & 0.184183 & 1.452722 & 1.074924 & 1.83052 \\
Height of obstruction (m) & 0.054537 & -0.19177 & -0.29043 & -0.0931 \\
Orientation $\left({ }^{\circ}\right)$ & 0.040972 & 0.038065 & 0.015309 & 0.060822 \\
\hline \multicolumn{2}{c|}{ Significance F < 0.05 in all four cases (significance level of 5\%) } \\
\hline \multicolumn{2}{r|}{ P-value < 0.05 (Significance level) in all four cases } \\
\hline
\end{tabular}


Table 4 - Solar Orientation x sDA

\begin{tabular}{c|c|c}
\hline \multirow{2}{*}{$\begin{array}{c}\text { Orientation } \\
(\mathbf{o})\end{array}$} & \multicolumn{2}{|c}{ Average sDA (\%) } \\
\cline { 2 - 3 } & Global & Street $>\mathbf{2 0 m}$ \\
\hline North & 52.83 & 79.8 \\
West & 65.67 & 100 \\
East & 68.45 & 100 \\
South & 75.59 & 100 \\
\hline
\end{tabular}

As a general outcome for this case-study located in the South hemisphere with low latitude and partly cloudy sky, solar orientation had a minor impact on sDA when compared with the other simulated urban parameters. In a room, highly obstructed by surrounding buildings, the indirect light provided by reflectance of front buildings seemed to be more important. This result reinforces the importance of the choice of reflectances in daylight urban simulations, and in future studies this parameter should be investigated. Assuming that based on the reflectance factor, in general, the worst performance of North orientation was compensated by the better ones in South, West, and East. Regarding the worst result for North, future studies could incorporate variations in the height of the canyon which contains the reference room. Henceforth, complementary studies should focus on the effect of distances between front buildings with pavilion (non-continuous) typology. Considering the findings here and the ones by Scalco and Pereira (2016), the variation of building footprints is a recommended option for future studies. The conclusions by Martins et al. (2013) may be used as reference for exploiting these overall results in terms of built density, verticality, compactness, and $\mathrm{H} / \mathrm{W}$ ratio.

Another outcome from the present study was that street widths should be defined higher than $10 \mathrm{~m}$, profusely from $15 \mathrm{~m}$ - the results tended to be better, $20 \mathrm{~m}$ obtained the optimum outputs. Room depth was found as the most relevant parameter for sDA in this Savannah. To favor minimum daylight levels, building depths that can provide room depths until $7 \mathrm{~m}$ (better $6 \mathrm{~m}$ ) should be stimulated when there is only one lateral window providing illuminance.

The sky angle of $27^{\circ} 30^{\circ}$ calculated by Assis and Valadares (1995) for daylight purposes in a similar climate and latitude may be beneficial for the sDA level in Cuiabá if, and only if, the room depths are restricted to $6 \mathrm{~m}$ with a high WWR. In case of the worst orientation, an $\mathrm{sDA}$ preferred $(\mathrm{sDA} \geq 75 \%)$ was observed in a room depth of $6 \mathrm{~m}$ combined to a sky angle of $34^{\circ}$; a minimum sky angle of $53^{\circ}$ is required for a depth of $7 \mathrm{~m}$.

The overall results indicated that $\operatorname{sDA}(300,50 \%)$, meaning 3001 ux indoor during $50 \%$ of the occupied time of the year, was feasible to achieve under these simulated conditions, but not easily. A major debate on the implications of this limit must be carried out, and maybe the inferior limit of $\mathrm{sDA} \geq 55 \%$ could be considered a reference for urban design in this latitude.

When the percentage $\mathrm{sDA} \geq 55 \%$ was adopted, the compliance cases increased significantly in number even for the worst solar orientation. For North (Figure 4), the percentages obtained from the cases with street of $5 \mathrm{~m}$ are all insufficient; however, almost all simulated conditions complied for front obstructions until 18m height (max.6 floors), and for room depth below $6 \mathrm{~m}$.

The general results of this study might be valid for a similar case of dense urban context under predominantly partly cloudy sky. However, additional studies are necessary to investigate to which extension.

\section{Conclusion}

This paper explored the quantitative comprehension of the relation between urban design based on increased density and daylight access to prevent unsatisfactory urban conditions and the excessive energy consumption for artificial lighting, in a Savanna.

An urban parametric simulation was developed for a low latitude city in Brazil (Cuiabá, $15^{\circ} 35^{\prime} \mathrm{S}$, $\left.56^{\circ} 05^{\prime} \mathrm{O}\right)$. The IES LM 83-12 (ILLUMINATING..., 2012) was adopted as a main guide for the simulation: based in this document, a Spatial Daylight Autonomy $\operatorname{sDA}(300,50 \%) \geq 75 \%$ was established as the minimum desirable condition for indoor daylight; visual comfort was not addressed. For a test reference room with variable depth located in a continuous urban canyon, solar orientation, height of dense front obstruction, and street width were varied.

For this city located in the South hemisphere and with predominantly partly cloudy sky, solar orientation had a minor impact on sDA when compared to other simulated urban parameters. For an optimized urban daylight design, considering the defined parameters here simulated, street widths $>$ $20 \mathrm{~m}$, room depths $<6 \mathrm{~m}$; height of front obstruction 
< $41 \mathrm{~m}$ (13 floors) offers the optimum scenario. In case of a room depth of $6 \mathrm{~m}$, a sky angle $>34^{\circ}$ already provides the minimum conditions. Room depth was found as the most relevant parameter for SDA in this case. Taking into account the results as per orientations, it is estimated that the differences of height between the sides of the canyon combined to outdoor reflectance were very significant aspects to sDA levels. The general results of this study are probably valid for similar cases; however, additional investigations are needed to confirm this and to which extension.

As an overall comment regarding the results, regression analysis was useful for determining the behavior and potential correlation between parameters; however, a complementary statistical method could add information regarding the most important aspects. Further simulations of window to wall ratio (WWR) should cover percentages lower than the $60 \%$ adopted here, which are more appropriate for the tropics and more representative of the residential sector. The definition of the threshold of 300lux and $75 \%$ was based on the researches which supported the IES LM 83-12 (ILLUMINATING..., 2012) for latitudes above $37^{\circ}$ and developed for determined occupant activities, since similar investigations on the preferences of occupants regarding daylight in the tropics where not found. The pertinent percentage defined as a threshold for sDA must be supplementary discussed and investigated, considering that it is the element from which results would support to shape the local urban design. Future research should also focus on variable reflectance, as well as other urban typologies. The comparison of results of sDA in different sky conditions, latitudes, indoor and outdoor configuration is also an opportunity for investigations.

Finally, even though daylight is fundamental for health, productivity, energy savings and livability of cities, there are still several gaps in studies dedicated to the effect of density. This paper aimed to fill a part of the gap regarding urban daylight design, but there still are several points missing that call for a collective effort in further investigations, especially within the tropics.

\section{References}

ALBUQUERQUE, M. S. C.; AMORIM, C. N. D. Iluminação Natural: indicações de profundidadelimite de ambientes para iluminação natural no Regulamento Técnico da Qualidade do Nível de Eficiência Energética de Edifícios Residenciais RTQ-R. Ambiente Construído, Porto Alegre, v. 12, n. 2, p. 37-57, abr./jun. 2012.
ALVES, M. C. et al. Effects of Sky Conditions Measured by the Clearness Index on the Estimation of Solar Radiation Using a Digital Elevation Mode. Atmospheric and Climate Sciences, v. 3, p. 618-626, 2013.

ASSIS, E. S.; VALADARES, V. M. Bases Para a Determinação dos Recuos e Volumetria dos Edifícios, Considerando a Insolação e Iluminação Natural, na Revisão da Lei de Uso e Ocupação do Solo de Belo Horizonte, MG. In: ENCONTRO NACIONAL DE CONFORTO NO AMBIENTE CONSTRUÍDO, 3., ENCONTRO LATINOAMERICANO DE CONFORTO NO AMBIENTE CONSTRUÍDO, 1995, Gramado. Anais... Gramado: ANTAC, 1995.

\section{ASSOCIAÇÃO BRASILEIRA DE NORMAS}

TÉCNICAS. NBR 5413: Iluminância de interiores. Rio de Janeiro, 1992.

\section{ASSOCIAÇÃO BRASILEIRA DE NORMAS TÉCNICAS. ABNT ISO/CI E 8995 -1: \\ iluminação de ambientes de trabalho: parte 1: interior. Rio de Janeiro, 2013.}

BHAVANI, R.; KHAN, M. Advanced Lighting Simulation Tools for Daylighting Purpose: powerful features and related issues. Trends in Applied Sciences Research, v. 6, n. 4, p. 345-63, 2011.

CABÚS, R. C. Validação do Programa TropLux. In: ENCONTRO NACIONAL DE CONFORTO NO AMBIENTE CONSTRUÍDO, 8., Maceió, 2005. Anais... Maceió, 2005.

CARLUCCI, S. et al. A Review of Indices for Assessing Visual Comfort With a View to Their Use in Optimization Processes to Support Building Integrated Design. Renewable and sustainable energy reviews, v. 47, p. 1016-1033, 2015.

CRAWLEY, D. B. Which Weather Data Should You Use for Energy Simulations of Commercial Buildings? ASHRAE Transactions, Atlanta, v. 104, p. 498-515, 1998.

DIAS, A. F. et al. Componentes de Controle de Luz Natural em Salas de Aula e seu Desempenho Conforme a Orientação Solar do Edifício. In: ENCONTRO LATINO-AMERICANO, 6.; ENCONTRO NACIONAL SOBRE CONFORTO NO AMBIENTE CONSTRUÍDO, 10., Natal, 2009. Anais... Natal, 2009.

GIVONI, B. Climate Considerations in Building and Urban Design. New York: John Wiley \& Sons, 2016.

GREEN BUILDING COUNCIL. LEED V4 for Building Design and Construction. Washington, DC: US Green Building Council, 2014. 
ILLUMINATING ENGINEERING SOCIETY OF NORTH AMERICA. IES LM 83-12: IES Spatial Daylight Autonomy (sDA) and Annual Sunlight Exposure (ASE). New York, 2012.

\section{INTERNATIONAL BUILDING}

PERFORMANCE SIMULATION ASSOCIATION. Weather Data for Building Performance Simulation. Session 3. Organizer: Rajan Rawal, presenters: Charles Barnaby, Drury Crawley. Online workshop: 06 Oct. 2016.

INTERNATIONAL ENERGY AGENCY. Energy Efficiency: Lighting, 2016

KOTTEK, M. et al. World Map of the KöppenGeiger Climate Classification Updated.

Meteorologische Zeitschrift, v. 15, n. 3, p. 259263, 2006.

LAMBERTS, R. et al. Análise de Arquivos Climáticos Para a Simulação do Desempenho Energético de Edificações. Florianópolis: Laboratório de Eficiência Energética em Edificações, 2015.

LARANJA, A. et al. Interferência da Orientação das Vias na Disponibilidade de Iluminação Natural do Ambiente Interno. In: ENCONTRO

NACIONAL DE TECNOLOGIA NO AMBIENTE CONSTRUÍDO, 14., Juiz de Fora, 2012. Anais... Juiz de Fora, 2012.

MARDALJEVIC, J. et al. Daylighting Metrics for Residential Buildings. In: COMMISSION INTERNATIONALE DE L'ÉCLAIRAGE, 27. Sun City, 2011. Proceedings... Sun City, 2011.

MARDALJEVIC, J. Daylight Simulation: validation, sky models and daylight coefficients. Montfort, 1999. Thesis (PhD) - Institute of Energy and Sustainable Development, De Montfort University, Montfort, 1999.

MARTINS, T. et al. Evaluation of the Impact of Urban Morphology on the Estimated Energy Demand of Buildings: a case study in Maceió, Brazil. Ambiente Construído, v.13, n. 4, p. 213233, out./dez. 2013.

NASROLLAHI, N.; SHOKRI, E. Daylight Illuminance in Urban Environments for Visual Comfort and Energy Performance. Renewable and Sustainable Energy Reviews, v. 66, p. 861$874,2016$.

NG, E. A Simplified Daylighting Design Tool for High-Density Urban Residential Buildings. Transactions of the Illuminating Engineering Society, v. 33, n. 4, p. 259-269, dec. 2001.
PAULE, B.; KAEMPF, Jérôme H. Daylighting: an approach from urban to room scale. In: BECKERS, B.; PICO, T.; JIMENEZ, S. (Eds.). INTERNATIONAL CONFERENCE ON URBAN PHYSICS, Quito, 2016. Proceedings... Quito, 2016.

PEREZ, R. et al. Modeling Daylight Availability and Irradiance Components from Direct and Global Irradiance. Solar Energy, v.44, n. 5, p. 271-289, 1990.

REINHART, C. F. Tutorial on the Use of Daysim Simulations For Sustainable Design. Ottawa: National Research Council Canada, 2006.

REINHART, C.; LOVERSO, V. A Rules of Thumb-Based Design Sequence for Diffuse Daylight. Lighting Research \& Technology, v. 42, n. 1, p. 7-31, Jan. 2010.

REINHART, C. Daylighting Handbook I: fundamentals, designing with the sun. 2014.

RORIZ, M. Arquivos Climáticos de Municípios Brasileiros. São Carlos, 2012. Relatório de Pesquisa.

SARATSIS, E. Daylit Density: a simulation-based framework towards performance-aware zoning and real estate development. Thesis - Massachusetts Institute of Technology, Department of Architecture, 2015.

SCALCO, V. A.; PEREIRA, F. O. R. Método Para a Avaliação do Impacto de Edificações no Acesso à Iluminação Natural em Vizinhanças Urbanas Aplicado em Cenários Virtuais. Ambiente Cosntruído, Porto Alegre, v. 16, n. 2, p. 169-187, abr./jun. 2016.

STRØMANN-ANDERSEN, J. B.; SATTRUP, P. A. The Urban Canyon and Building Energy Use: urban density versus daylight and passive solar gains. Energy and Buildings, v. 43, n. 8, p. 2011 2020, 2011.

TSANGRASSOULIS, A. et al. A Method For The Estimation Of Illuminances On Surfaces Of Urban Canyons With Balconies In Sunlit Areas.

International Journal of Lighting Research and Technology, v. 31, n. 1, p. 5-12, mar. 1999.

UNITED NATIONS. Department of Economic and Social Affairs, Population Division. World Urbanization Prospects: The 2014 Revision. Highlights (ST/ESA/SER.A/352). 2014.

U.S. NATIONAL RENEWABLE ENERGY LABORATORY. Renewable Resource Data Center. User's Manual for TMY2s- Typical Meteorological Years. APPENDIX A: Procedures for Developing TMY2s, 1995. 
WAGDY, A. et al. Daylighting Optimization for Informal Settlements in Cairo, Egypt. In:

INTERNATIONAL BUILDING

PERFORMANCE SIMULATION

ASSOCIATION, 2015. Proceedings... 2015.

\section{Aknowledgements}

The authors acknowledge the Brazilian National Council for Scientific and Technological Development - $\mathrm{CNPq}$ for the financial support for one of the authors under the "Science without
Borders" programme; Technische Universität München for the infrastructure; Transsolar Energietechnik $\mathrm{GmbH}$ in the person of Dietmar Geiselmann for the evaluation of preliminary results of the simulation; Ata Chokhachian, Mark Sen Dong, Boris Plotnikov for support in the use of the software Grasshopper; Prof. Dr. Rodrigo Cardoso from CEFET-MG for the support in Multivariate Analysis and Statistics. Bashar Dwaik for image treatment. Gaurie Lakhanpal for the inicial proofreading in English language.

Iara Gonçalves dos Santos

Chair of Building Technology and Climate Responsive Design, Department of Architecture | Technical University of Munich | Arcisstrasse 21 | Munich - Germany | 80333 | Tel.: +(49) 89 289-22475 | E-mail: iaragds@yahoo.com.br

\section{Thomas Auer}

Chair of Building Technology and Climate Responsive Design, Department of Architecture | Technical University of Munich | E-mail: thomas.auer@lrz.tu-muenchen.de

\section{Roberta Vieira Gonçalves de Souza}

Departamento de Tecnologia da Arquitetura e do Urbanismo, Escola de Arquitetura | Universidade Federal de Minas Gerais | Rua Paraíba 697, Sala 124, Funcionários | Belo Horizonte - MG - Brasil | CEP 30130-140 | Tel.: (31) 3409-8872 | E-mail: robertavgs2@gmail.com

\section{Revista Ambiente Construído}

Associação Nacional de Tecnologia do Ambiente Construído

Av. Osvaldo Aranha, 99 - $3^{\circ}$ andar, Centro

Porto Alegre - RS - Brasil

CEP 90035-190

Telefone: +55 (51) 3308-4084

Fax: +55 (51) 3308-4054

www.seer.ufrgs.br/ambienteconstruido

E-mail: ambienteconstruido@ufrgs.br 